\title{
An analysis of oral biopsies extracted from 1995 to 2009, in an oral medicine and surgery unit in Galicia (Spain)
}

\author{
Raquel Sixto-Requeijo ${ }^{1}$, Marco Diniz-Freitas ${ }^{1}$, Juan-Carlos Torreira-Lorenzo ${ }^{1}$, Abel García-García ${ }^{2}$, José \\ M. Gándara-Rey ${ }^{3}$
}

\begin{abstract}
${ }^{1}$ Dentist. Assistant Professor of the Master of Oral Medicine, Surgery and Implantology of the Faculty of Dentistry of the University of Santiago de Compostela

${ }^{2}$ Professor of the Oral and Maxilofacial Unit. Faculty of Dentistry of the University of Santiago de Compostela. Head of the Maxilofacial Surgery Unit of the Santiago de Compostela Teaching Hospital

${ }^{3}$ Professor of the Oral and Maxilofacial Unit of the Faculty of Dentistry of the University of Santiago de Compostela
\end{abstract}

Correspondence:

Facultad de Odontología

Departamento de Medicina Oral

C/Entrerrios $s / n$

C.P. 15782 Santiago de Compostela, Spain

raquelsixto@gmail.com

Received: 08/06/2010

Accepted: 16/01/2011
Sixto-Requeijo R, Diniz-Freitas M, Torreira-Lorenzo JC, García-García A, Gándara-Rey JM. An analysis of oral biopsies extracted from 1995 to 2009 , in an oral medicine and surgery unit in Galicia (Spain). Med Oral Patol Oral Cir Bucal. 2012 Jan 1;17 (1):e16-22.

http://www.medicinaoral.com/medoralfree01/v17i1/medoralv17ilp16.pdf

Article Number: 17143 http://www.medicinaoral.com/

(C) Medicina Oral S. L. C.I.F. B 96689336 - pISSN 1698-4447 - eISSN: 1698-6946

eMail: medicina@medicinaoral.com

Indexed in:

Science Citation Index Expanded

Journal Citation Reports

Index Medicus, MEDLINE, PubMed

Scopus, Embase and Emcare

Indice Médico Español

\begin{abstract}
Objective: To conduct an analysis of the frequency of oral lesions in biopsies over a 14-year period in the Oral Medicine, Oral Surgery and Implantology Unit.

Material and Methods: We conducted a retrospective study of biopsies removed from 1995-2009, recording data regarding age, sex, location of the lesions, biopsy types, anatomical and pathological diagnosis and definitive diagnosis.

Results: Of the 562 patients studied, the average age was 51.8 years, with a standard deviation of 18.5 (range 5-96). The distribution by sex was 318 (56.6\%) women and 244 (43.4\%) men. The most common diagnostic category was mucosal pathologies in $37.9 \%$ of cases, followed by odontogenic cysts in $27.8 \%$. Malignant tumors accounted for $3.9 \%$ of cases, oral squamous cell carcinomas were the most frequent malignancy, appearing in 22 cases. Bisphosphonate-related osteonecrosis of the jaws was the most common injury within the bone lesions group.

Conclusion: Following the performance of 647 biopsies on 562 patients, we can say that the most common injury was radicular cysts (appearing in 108 cases), having found statistical differences in relation to the patients' sex and age.
\end{abstract}

Key words: Frequency, oral pathology, biopsy. 


\section{Introduction}

Conducting an overall and detailed medical history and a comprehensive exploration of the oral cavity is essential to obtain correct diagnosis. Moreover this influences the prognosis and the implementation of the appropriate treatment for each patient. Thus we can detect existing lesions early, which is essential in malignancies and will guide the evolution and prognosis of the disease. Although occasionally it is possible to establish a clinical diagnosis, in most cases it is essential to conduct additional simple tests that provide valuable information, such as biopsies, which are a very useful diagnostic tool. In this paper we present the findings resulting of the analysis of 647 biopsies, performed over a 14-year period in the Master of Oral Medicine, Oral Surgery and Implantology at the University of Santiago de Compostela.

\section{Material and Methods}

We conducted a retrospective study of biopsies removed from 1995-2009 at the Master of Oral Medicine, Oral Surgery and Implantology at the University of Santiago

Table 1. Classification of diagnoses by categories.

\begin{tabular}{|c|l|}
\hline Mucosal pathology & $\begin{array}{l}\text { Lupus, lichen, actinic cheilitis, papilloma, leukoplakia, erythroplasia, hyperkeratosis, } \\
\text { traumatic ulceration, fissured epulis, chronic hyperplastic candidiasis, palmoplantar } \\
\text { keratoderma, hyperplasia, chronic gingivitis desquamative, exudative erythema } \\
\text { multiforme, pemphigus, pemphigoid, median rhomboid glossitis, white sponge nevus, } \\
\text { verruca vulgaris. }\end{array}$ \\
\hline Odontogenic cysts & Radicular cyst, dentigerous cyst, residual cyst. \\
\hline Dental pathology & Granuloma \\
\hline Miscellaneous & $\begin{array}{l}\text { Melanotic macule, peri-implantitis, epithelial necrosis, amalgam tattoo, plasma cell } \\
\text { granuloma, inflammatory polyp, epidermoid cyst, non-specific ulcer, Klestadt's cyst. }\end{array}$ \\
\hline $\begin{array}{c}\text { Salivary gland disease } \\
\text { Periodontal disease }\end{array}$ & Mucocele, ranula, bacterial sialadenitis, Sjögren's syndrome, pleomorphic adenoma. \\
\hline Palignant tumors & Non-Hodgkin lymphoma, adenoid carcinoma, oral squamous cell carcinoma. \\
\hline Bone Pathology & $\begin{array}{l}\text { Bisphosphonate-related osteonecrosis of the jaws, palatine torus, osteoma, central giant } \\
\text { cell lesion. }\end{array}$ \\
\hline $\begin{array}{c}\text { Connective tissue } \\
\text { disease }\end{array}$ & $\begin{array}{l}\text { Fibroma, angioma, fibromatosis, amyloidosis, cavernous hemangioma, neurofibroma, } \\
\text { capillary hemangioma. }\end{array}$ \\
\hline $\begin{array}{l}\text { Odontogenic tumors } \\
\text { Keratocyst }\end{array}$ \\
\hline
\end{tabular}

Table 2. Diagnosis by category.

\begin{tabular}{|c|c|c|c|c|c|}
\hline Dx category & 9 & $\hat{0}$ & No & $\stackrel{0}{0} 0^{\lambda}$ & $\%$ \\
\hline Path. Mucosa & 140 & 105 & 245 & 1.3 & $37.9 \%$ \\
\hline Odontogenic $\mathrm{C}$. & 97 & 80 & 177 & 1.2 & $27.4 \%$ \\
\hline Path. Dental & 11 & 7 & 18 & 1.6 & $2.8 \%$ \\
\hline Miscellaneous & 12 & 13 & 25 & 0.9 & $3.9 \%$ \\
\hline Path. Salivary Glands & 20 & 14 & 34 & 1.4 & $5.3 \%$ \\
\hline Path. Periodontal & 14 & 12 & 26 & 1.2 & $4.0 \%$ \\
\hline Malignant T. & 13 & 12 & 25 & 1.1 & $3.9 \%$ \\
\hline Bone Pathology & 4 & 3 & 7 & 1.3 & $1.1 \%$ \\
\hline Path. Con. T. & 59 & 28 & 87 & 2.1 & $13.4 \%$ \\
\hline Odontogenic tumor & 2 & 1 & 3 & 2 & $0.5 \%$ \\
\hline TOTAL & 372 & 275 & 647 & & $100 \%$ \\
\hline
\end{tabular}

*Path: pathology; C.: cyst; Path..Saliv. Gland: pathology of salivary glands T.: Tumors; Path. Con. T.: pathology in connective tissue; Odontogenic T.: odontogenic tumors. 
de Compostela. We reviewed the medical records of all patients undergoing the biopsies during this period, excluding cases in which we removed more than one biopsy from the same lesion and when any of the following data was missing: age, sex, location of lesions, type of biopsy, anatomical and pathological analysis and definitive diagnosis. Most patients were referred to our unit from different parts of Galicia, through the Galician Public Health Care Service (SERGAS) and private practices.

Table 3. Contingency table. Sex and histological diagnosis (grouped by diagnostic categories).

PATHOLOGY OF THE MUCOSA.

\begin{tabular}{|c|c|c|c|c|c|}
\hline Diagnosis & Q & $\hat{0}$ & Total & (\%group) & (\%total) \\
\hline Lupus & 3 & 0 & 3 & 1.2 & 0.5 \\
\hline Lichen & 54 & 37 & 91 & 37.1 & 14.1 \\
\hline Actinic cheilitis & 0 & 2 & 2 & 0.8 & 0.3 \\
\hline Papilloma & 16 & 8 & 24 & 9.8 & 3.7 \\
\hline Leukoplakia & 54 & 46 & 100 & 40.8 & 15.5 \\
\hline Erythroplasia & 1 & 0 & 1 & 0.4 & 0.2 \\
\hline Hyperkeratosis & 2 & 1 & 3 & 1.2 & 0.5 \\
\hline Traumatic ulcer & 2 & 1 & 3 & 1.2 & 0.5 \\
\hline Fissured epulis & 0 & 1 & 1 & 0.4 & 0.2 \\
\hline Chronic H. candidiasis & 1 & 3 & 4 & 1.6 & 0.6 \\
\hline Keratoderma P-P & 1 & 0 & 1 & 0.4 & 0.2 \\
\hline Hyperplasia & 0 & 3 & 3 & 1.2 & 0.5 \\
\hline $\mathrm{CDG}$ & 1 & 0 & 1 & 0.4 & 0.2 \\
\hline Exudative erythema & 0 & 1 & 1 & 0.4 & 0.2 \\
\hline Pemphigus & 3 & 0 & 3 & 1.2 & 0.5 \\
\hline Pemphigoid & 1 & 0 & 1 & 0.4 & 0.2 \\
\hline Rhomboid glossitis & 1 & 0 & 1 & 0.4 & 0.2 \\
\hline White sponge $\mathrm{n}$. & 0 & 1 & 1 & 0.4 & 0.2 \\
\hline Verruca vulgaris & 0 & 1 & 1 & 0.4 & 0.2 \\
\hline TOTAL & 140 & 105 & 245 & & \\
\hline
\end{tabular}

* Chronic H. Candidiasis: chronic hyperplastic candidiasis; P-P keratoderma: palmoplantar keratoderma; CDG: chronic desquamative gingivitis, White sponge n: white sponge nevus ODONTOGENIC C.

\begin{tabular}{|c|c|c|c|c|c|}
\hline Diagnosis & 9 & $\hat{0}$ & Total & (\%group) & (\%total) \\
\hline Radicular C. (Apical) & 65 & 43 & 108 & 61 & 16.7 \\
\hline $\begin{array}{l}\text { Dentigerous C. } \\
\text { (follicular) }\end{array}$ & 29 & 32 & 61 & 34.4 & 9.4 \\
\hline Residual C. & 3 & 5 & 8 & 4.5 & 1.2 \\
\hline TOTAL & 97 & 80 & 177 & & \\
\hline \multicolumn{6}{|l|}{ DENTAL PATHOLOGY } \\
\hline Diagnosis & 우 & $\hat{0}$ & Total & (\%group) & (\%total) \\
\hline Periapical granuloma & 11 & 7 & 18 & 100 & 2.8 \\
\hline TOTAL & 11 & 7 & 18 & & \\
\hline \multicolumn{6}{|l|}{ MISCELLANEOUS } \\
\hline Diagnosis & 우 & $\hat{0}$ & Total & (\%group) & (\%total) \\
\hline Melanotic macule & 2 & 1 & 3 & 12.0 & 0.5 \\
\hline Peri-implantitis & 1 & 0 & 1 & 4.0 & 0.2 \\
\hline Amalgam tattoo & 3 & 0 & 3 & 12.0 & 0.5 \\
\hline P. C. Granuloma & 1 & 2 & 3 & 12.0 & 0.5 \\
\hline Inflammatory polyp & 1 & 1 & 2 & 8.0 & 0.3 \\
\hline Nasolabial C. & 0 & 1 & 1 & 4.0 & 0.2 \\
\hline Epithelial necrosis & 0 & 1 & 1 & 4.0 & 0.2 \\
\hline Unspec. Ulcer & 3 & 7 & 10 & 40.0 & 1.5 \\
\hline Epidermoid C. & 1 & 0 & 1 & 4.0 & 0.2 \\
\hline TOTAL & 12 & 13 & 25 & & \\
\hline
\end{tabular}

* P.C. Granuloma: Plasma cell granuloma; Nasolabial C.: Nasolabial cyst; Epidermoid C: Epidermoid Cyst." 
SALIVARY GLANDS

\begin{tabular}{|c|c|c|c|c|c|}
\hline Diagnosis & 오 & $\hat{0}$ & Total & (\%group) & (\%total) \\
\hline Mucocele & 15 & 13 & 28 & 82.4 & 4.3 \\
\hline Ranula & 1 & 0 & 1 & 2.9 & 0.2 \\
\hline Bacterial sialadenitis & 0 & 1 & 1 & 2.9 & 0.2 \\
\hline Sjögren's syndrome & 3 & 0 & 3 & 8.8 & 0.5 \\
\hline Pleomorphic adenoma & 1 & 0 & 1 & 2.9 & 0.2 \\
\hline $\begin{array}{c}\text { TOTAL } \\
\end{array}$ & 20 & 14 & 34 & & \\
\hline \multicolumn{6}{|c|}{ PERIODONTAL DISEASE } \\
\hline Diagnosis & 오 & $\hat{0}$ & Total & (\%group) & (\%total) \\
\hline Hyperplasia & 2 & 1 & 3 & 11.5 & 0.5 \\
\hline $\begin{array}{l}\text { Peripheral giant cell } \\
\text { lesion }\end{array}$ & 3 & 6 & 9 & 34.6 & 1.4 \\
\hline Pyogenic granuloma & 9 & 5 & 14 & 53.8 & 2.2 \\
\hline TOTAL & 14 & 12 & 26 & & \\
\hline \multicolumn{6}{|l|}{ MALIGNANT TUMORS } \\
\hline Diagnosis & q & $\overline{0}$ & Total & (\%group) & (\%total) \\
\hline OSCC & 10 & 12 & 22 & 88.0 & 3.4 \\
\hline NHL & 2 & 0 & 2 & 8.0 & 0.3 \\
\hline Adenoid carcinoma & 1 & 0 & 1 & 4.0 & 0.2 \\
\hline TOTAL & 13 & 12 & 25 & & \\
\hline
\end{tabular}

* OSCC: oral squamous cell carcinoma; NHL: Non-Hodgkin lymphoma. BONE PATHOLOGY

\begin{tabular}{|l|ccccc|}
\hline Diagnosis & $\circ$ & 0 & Total & (\%group) & (\%total) \\
\hline BRONJ & 2 & 2 & 4 & 57.1 & 0.6 \\
Palatine Torus & 1 & 0 & 1 & 14.3 & 0.2 \\
Osteoma & 0 & 1 & 1 & 14.3 & 0.2 \\
Central giant cell lesion & 1 & 0 & 1 & 14.3 & 0.2 \\
\hline \multicolumn{1}{|c|}{ TOTAL } & 4 & 3 & 7 & & \\
\hline
\end{tabular}

* BRONJ: Bisphosphonate-Related Osteonecrosis of the Jaws. CONNECTIVE TISSUE DISEASE

\begin{tabular}{|c|c|c|c|c|c|}
\hline Diagnosis & 오 & $\hat{0}$ & Total & (\%group) & (\%total) \\
\hline Fibroma & 51 & 23 & 74 & 85.1 & 11.4 \\
\hline Angioma & 3 & 0 & 3 & 3.4 & 0.5 \\
\hline Fibromatosis & 1 & 0 & 1 & 1.1 & 0.2 \\
\hline Amyloidosis & 1 & 1 & 2 & 2.3 & 0.3 \\
\hline Cavernous & 1 & 2 & 3 & 3.4 & 0.5 \\
\hline Hemangioma & & & & & \\
\hline Neurofibroma & 0 & 2 & 2 & 2.3 & 0.3 \\
\hline Capillary Hemangioma & 2 & 0 & 2 & 2.3 & 0.3 \\
\hline $\begin{array}{c}\text { TOTAL } \\
\end{array}$ & 59 & 28 & 87 & & \\
\hline \multicolumn{6}{|c|}{ ODONTOGENIC TUMORS } \\
\hline Diagnosis & 오 & 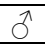 & Total & (\%group) & (\%total) \\
\hline Keratocyst & 2 & 1 & 3 & 100 & 0.5 \\
\hline TOTAL & 2 & 1 & 3 & & \\
\hline
\end{tabular}

Lesions were then classified in 10 diagnostic categories, as detailed in (Table 1). All results were subjected to statistical analysis using SPSS 12.0 for Windows Xp.

\section{Results}

The number of patients studied was 562, which is less than the number of samples, indicating that in some cases more than one biopsy was taken. The average age of these patients was 51.8 with a standard deviation of 18.5 years (range 5-96). In terms of distribution according to sex $318(56.6 \%)$ were women, whose average age was $51.2 \pm 18.8$ (standard deviation) and 244 (43.4\%) men, whose average age was 50,1 \pm 18.3 (standard deviation). The most common type of biopsy was excisional biopsy amounting to $66.5 \%$. The most frequent lesion observed were radicular cysts, appearing in 108 cases (16.7\%) followed by leukoplakia with 100 cases (15.5\%), of which 15 showed different degrees of dysplasia in the histopathological study. The third most common lesion was lichen planus reaching $14.1 \%$, followed by fibroma (11.4\%). The prevalence of the diagnostic categories and their distribution with respect to sex can be seen in (Table 2).

The most common injury in women was radicular cysts 
Table 4. Prevalence of lesions according to age group.

\begin{tabular}{|l|c|c|c|c|}
\hline Age groups & No & $\mathbf{\%}$ & Most frequent $\mathbf{D}_{\mathbf{x}}$ & \% per group \\
\hline 1 [0-15 years] & 11 & 1.7 & Mucocele & 36.4 \\
2 [16-30 years] & 88 & 13.6 & Dentigerous cyst & 32.9 \\
3 [31-65 years] & 365 & 56.4 & Radicular C. & 19.5 \\
4 [ $\geq 6$ years] & 183 & 28.3 & Leukoplakia & 28.4 \\
\hline \multicolumn{1}{|c|}{ TOTAL } & 647 & 100 & & \\
\hline
\end{tabular}

amounting to 65 cases; while in men leukoplakia appeared in 46 samples. The distribution of other lesions in relation to sex can be seen, distributed by diagnostic categories, in (Table 3).

Regarding the location, the most frequent injuries were those associated with a tooth, with a frequency of $23 \%$, followed by gums (16.7\%), tongue (15.9\%), buccal mucosa $(15.9 \%)$, lower lip (6\%) and lesions associated with the third molar (5.9\%), all other lesions amounted to less than $5 \%$. The most frequent tooth injury was radicular cysts (apical); leukoplakia in the gum; lichen planus in buccal mucosa; leukoplakia in the tongue and mucocele in the lower lip area.

We divided the study population into 4 age groups, the results and most common diagnoses; as shown in (Table 4).

\section{Discussion}

In this study the number of lesions studied is much lower than those in other studies $(1,2)$. Like other authors (1) we found a higher frequency of lesions in women, which can be easily explained since there are more women in our population, however, men showed a higher number of cases of actinic cheilitis and oral squamous cell carcinoma. The mean age was 51.8 years \pm 18.5 (standard deviation) without excluding any group of children (3), therefore some results differ from those in other published studies, such as the study by Jones and Franklin (1), who only took into account patients over 17, or Das and Das (4) who studied injuries in children up to 20; and Shulman et al. (5), or Corrêa et al. (2) who focused their study on elderly patients (over 60). Nor have we focused on a particular condition or location as in other studies (6-8).

By studying each diagnostic category separately, there are differences between our results and those of other authors (1) but these can be explained by changes made in classifying the various injuries in each diagnostic category. Given that our center is a specialized in oral medicine, thus a large number of cases with different mucosal diseases are referred to us from different parts of Galicia, both through the Galician Public Health Care Service (SERGAS) and through private practices, as mentioned above.

Dental and periodontal pathologies

The most frequent dental pathology, as in other studies
(1), was the periapical granuloma amounting to $2.8 \%$ of the total, a result lower than the one recorded by Jones and Franklin (1) who set it at $8.1 \%$ or Satorres et al. (9) (18.1\%). Within the category of periodontal diseases pyogenic granuloma was the most common amounting to $53.8 \%(2.2 \%$ of total $)$, a figure above those found in other studies (1) where the percentage was $31.8 \%$ within the group, but in our case this was due to the small sample size and the changes we made in classifying the lesions within the different diagnostic categories. The second most frequent diagnosis in this group was peripheral giant cell granuloma appearing in 9 cases (34.6\%) (10).

\section{Odontogenic cysts}

With $27.8 \%$ of cases, this group stands second in frequency after pathology of the mucous membranes, figures higher than those recorded by other authors (14.9\%) (11). Radicular cysts were the most prevalent lesion appearing in 108 cases, with a rate of $60 \%$ of all odontogenic cysts $(16.7 \%$ of total). These results agree with other studies (11-17), which place periapical cysts as the most common odontogenic cysts, 39.9\% (8), 50.7\% (11), being the diagnosis showing the highest rates outside the odontogenic cysts' group 19.5\% (9), 41.2\% (12). The second most common is the dentigerous cyst accounting for $33.9 \%$ of the group (9.4\% of total) figures that are very similar to those found by Mosqueda et al. (33\%) (8) but higher than those recorded by Tay (2.3\%) (11); however, this may be due to sample size.

\section{Bone Pathology}

In our study bisphosphonate-related osteonecrosis of the jaws was the largest lesion in this group accounting for $57.1 \%$ and $0.61 \%$ of the total. All cases were cancer patients treated with intravenous bisphosphonates to prevent bone metastases that had undergone dental extractions during treatment or suffered spontaneous loss of teeth. The data we found is not easily comparable, since similar studies are lacking biopsy data in cases diagnosed with bisphosphonates associated osteonecrosis (18-20). A rough estimate of this complication's incidence could be drafted (namely, $0.8-12 \%$ in IV, and $0.01-0.04 \%$ in oral) (19); but further studies are required in the long term.

Mucosal pathology

Leukoplakia was the most common lesion in this group, 100 cases (40.8\% of group and $15.5 \%$ of total), showing 
various degrees of dysplasia in 15 of them, followed by lichen planus (37.1\% of the group, $14.1 \%$ of total), which were also among the most common injuries in other studies $(1,2)$. All the cases were found in adults over age 30 , in fact, research such as the one conducted by Corrêa et al. (2), who studied oral diseases in patients over 60 years, found that lichen planus reached a frequency of $61.29 \%$.

\section{Connective tissue disease}

Fibroma was the most common injury with $85.1 \%$, representing $11.4 \%$ of the total. Its frequency was higher in women than in men of order 2.2:1, and the most common location were the buccal mucosa, gums and tongue. Torres et al. (6) in their study of 300 patients with benign tumors of the oral cavity found fibroma with a frequency of $53.3 \%$, showing higher frequency in women than in men. However, these results are much higher than those reported by other authors $(1,16,21)$.

\section{Salivary glands disease}

The most frequent injury was mucocele, which represented $4.3 \%$ of all injuries, appearing primarily among younger individuals (under 30). Although percentages vary between authors, $7.81 \%$ (17), 11.6\% (4), 19.2\% (22), it is considered the most frequent lesion of the salivary glands with a greater presence in children and young people who are particularly vulnerable, especially in the lower lip area, mainly due to its etiological association with traumatic factors $(1,4,16)$.

\section{Malignant tumors}

The group of malignant tumors accounted for 3.9\%. Oral squamous cell carcinoma is considered the most common malignancy of the oral cavity appearing mostly on the tongue and lower lip. In our study it amounted to $88 \%$ of all malignant lesions ( $3.4 \%$ of total), the most common location was the tongue (14 cases), and its appearance was higher in men and in patients belonging to the fourth age group ( $\geq 66$ years). Jones and Franklin (1) reported that oral squamous cell carcinoma was the most common malignancy in their study (66.1\%) with a higher prevalence in men, with an average age of 64.2 years. Mujica et al. (3) found that oral squamous cell carcinomas showed frequency of $2 \%$ among 306 injuries, while Satorres et al. recorded 1\% (9) and Skinner and Weir (23) reported 5.4\% in 2675 samples, but this higher percentage is due to the fact that their study population was older than 55 .

\section{Odontogenic tumors}

Although works, such as the one by Jones and Franklin (1), account for a larger number of injuries within this group, however, we have only found keratocysts, showing $0.5 \%$ frequency over the total; these figures are similar to those published in other papers $0.01 \%$ (1) $0.8 \%$ (23).

Ultimately, we can conclude that radicular cysts were the most common lesion found in our work, with 108 cases and a higher prevalence in adults (16-65 years).
Likewise, the percentage of injuries was higher in women, although the frequency of premalignant and malignant lesions was higher in men over age 50 .

\section{References}

\section{References with links to Crossref - DOI}

1. Jones AV, Franklin CD. An analysis of oral and maxillofacial pathology found in adults over a 30-year period. J Oral Pathol Med. 2006;35:392-401.

2. Corrêa L, Frigerio ML, Sousa SC, Novelli MD. Oral lesions in elderly population: a biopsy survey using 2250 histopathological records. Gerodontology. 2006;23:48-54.

3. Mujica V, Rivera H, Carrero M. Prevalence of oral soft tissue lesions in an elderly venezuelan population. Med Oral Patol Oral Cir Bucal. 2008;13:E270-4.

4. Das S, Das AK. A review of pediatric oral biopsies from a surgical pathology service in a dental school. Pediatr Dent. 1993;15:208-11.

5. Shulman JD, Beach MM, Rivera-Hidalgo F. The prevalence of oral mucosal lesions in U.S. adults: data from the Third National Health and Nutrition Examination Survey, 1988-1994. J Am Dent Assoc. 2004;135:1279-86.

6. Torres-Domingo S, Bagan JV, Jiménez Y, Poveda R, Murillo J, Díaz JM, et al. Benign tumors of the oral mucosa: a study of 300 patients. Med Oral Patol Oral Cir Bucal. 2008;13:E161-6.

7. Shamim T, Varghese VI, Shameena PM, Sudha S. A retrospective analysis of gingival biopsied lesions in South Indian population: 2001-2006. Med Oral Patol Oral Cir Bucal. 2008;13:E414-8.

8. Mosqueda-Taylor A, Irigoyen-Camacho ME, Diaz-Franco MA, Torres-Tejero MA. Odontogenic cysts. Analysis of 856 cases. Med Oral. 2002;7:89-96.

9. Satorres Nieto M, Faura Solé M, Brescó Salinas M, Berini Aytés L, Gay Escoda C. Prevalence of biopsied oral lesions in a service of oral surgery. Med Oral. 2001;6:296-305.

10. Gandara-Rey JM, Pacheco Martins Carneiro JL, Gandara-Vila $\mathrm{P}$, Blanco-Carrion A, García-García A, Madriñán-Graña $\mathrm{P}$, et al. Peripheral giant-cell granuloma. Review of 13 cases. Med Oral. 2002;7:254-9.

11. Tay AB. A 5-year survey of oral biopsies in an oral surgical unit in Singapore: 1993-1997. Ann Acad Med Singapore. 1999;28:665-71.

12. Nakamura T, Ishida J, Nakano Y, Ishii T, Fukumoto M, Izumi H, et al. A study of cysts in the oral region. Cysts of the jaw. J Nihon Univ Sch Dent. 1995;37:33-40.

13. Shear M. Cysts of the jaws: recent advances. J Oral Pathol. 1985;14:43-59.

14. Ackermann G, Cohen MA, Altini M. The paradental cyst: a clinicopathologic study of 50 cases. Oral Surg Oral Med Oral Pathol. 1987;64:308-12.

15. Daley TD, Wysocki GP, Pringle GA. Relative incidence of odontogenic tumors and oral and jaw cysts in a Canadian population. Oral Surg Oral Med Oral Pathol. 1994;77:276-80.

16. Bhaskar SN. Oral pathology in the dental office: survey of 20,575 biopsy specimens. J Am Dent Assoc. 1968;76:761-6.

17. Maia DM, Merly F, Castro WH, Gomez RS. A survey of oral biopsies in Brazilian pediatric patients. ASDC J Dent Child. 2000;67:12831,83 .

18. Marx RE. Pamidronate (Aredia) and zoledronate (Zometa) induced avascular necrosis of the jaws: a growing epidemic. J Oral Maxillofac Surg. 2003;61:1115-7.

19. Ruggiero SL, Dodson TB, Assael LA, Landesberg R, Marx RE, Mehrotra B, et al. American Association of Oral and Maxillofacial Surgeons position paper on bisphosphonate-related osteonecrosis of the jaws-2009 update. J Oral Maxillofac Surg. 2009;67:2-12.

20. Bagan JV, Murillo J, Jimenez Y, Poveda R, Milian MA, Sanchis $\mathrm{JM}$, et al. Avascular jaw osteonecrosis in association with cancer chemotherapy: series of 10 cases. J Oral Pathol Med. 2005;34:120-3. 21. Bouquot JE. Common oral lesions found during a mass screening examination. J Am Dent Assoc. 1986;112:50-7. 
22. Chidzonga MM, Lopez VM, Portilla Alvarez AL. Orofacial biopsies: a survey of 1,723 cases seen over a 10 year period. Cent Afr J Med. 1996;42:102-8.

23. Skinner RL, Weir JC. Histologic diagnoses of oral lesions in geriatric dental patients: a survey of biopsied lesions. Gerodontics. 1987;3:198-200. 